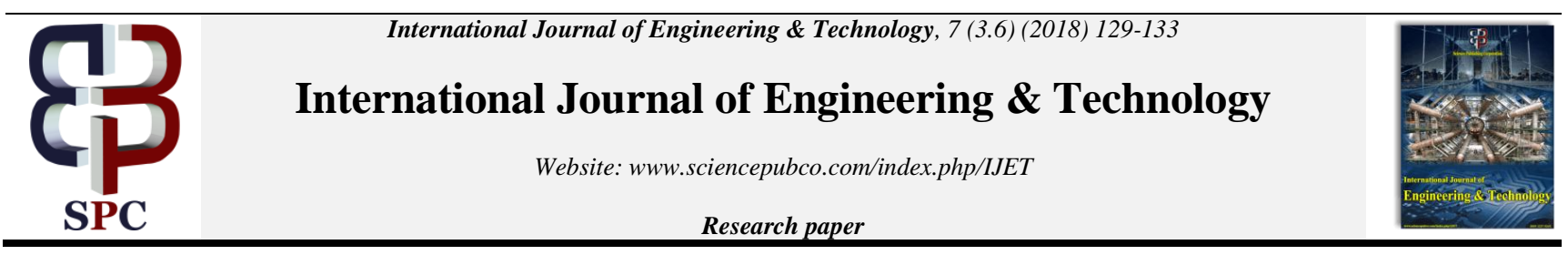

\title{
Job Satisfaction of Female Faculty in Arts and Science Colleges in Coimbatore District
}

\author{
V. Sumathi ${ }^{1^{*}}$, R. Velmurugan ${ }^{2}$ \\ ${ }^{I}$ Ph.D. Research Scholar, Management, Karpagam Academy Of Higher Education, Coimbatore. \\ ${ }^{2}$ Associate Professor, Commerce, Karpagam Academy Of Higher Education, Coimbatore. \\ E-Mail:Drvelsngm@Gmail.Com \\ *Corresponding Author E-Mail:Sumathiganesh18@Gmail.Com
}

\begin{abstract}
Productive contribution of teachers towards institution and student development depends on not only their educational qualification and experience but also their job satisfaction. Satisfied teachers will contribute more towards institution and student enrichment. So, it is the duty of management of educational institutions to keep their faculty satisfied for their long-term survival. In this study an earnest attempt has been made to ascertain the factors influencing job satisfaction of women staff members working at Arts and Science Colleges in Coimbatore District. The result of the study portrays that women faculty are satisfied with regard to recognition received from their superiors followed by revision of salary (Ausekar, 1996), salary offered (Sharma, 2005), increment offered by the management for acquiring additional educational qualification etc.
\end{abstract}

Keywords: Work life balance, job satisfaction.

\section{Introduction}

Teaching is considered a dignified career, enjoying high esteem in society. Teaching offers a high level of satisfaction, as teachers transform their knowledge, skills and show a right path to the young citizens of a country. Teaching is not a job but a commitment because a teacher deals with young minds. He has to shape his students into better citizens. His actions and personality directly influence the lives of the students. Nowadays, many students prefer to enter the lucrative software field and to settle down comfortably. Hence, many people hesitate to choose this profession. But still, there are people who become teachers and have succeeded in their career. Teaching profession needs a great deal of patience and talent to deal with students.

There are many factors which play an important part in the success of educational institutions like faculty, infrastructure, other resources etc. But, from them "teachers" are the most important factors for the success rate of educational institutions. So, it is essential for every management to effectively utilize their teachers. In an educational institution every teacher is assigned a certain set of tasks to perform and the skills he displays performing it defines him. Every management believes that "Satisfied teachers can bring their institution success." So, it is very important for every management to identify whether their employees are really satisfied or not. And Job satisfaction survey is a tool to check whether a person is happy with his job or not. It is important for every institution to know the job satisfaction level of their employees because the success of the institutions is dependent to a great extent upon the satisfied employees of the institution. Satisfaction refers to individual elements of one's job, like salary, growth prospects, physical environment, working hours and so on.
Human Resource unarguably is one of the most valuable assets of any organization and more so for the educational institutions because they operate on the human intellectual capital. It is therefore essential to retain the educated, committed and experienced staff in order to be able to maintain the knowledge inventory and reduce the cost of re-recruitment, selection, orientation, training and development on new staff. Being able to retain the staff will also ensure knowledge continuity, committed decision making and smooth and coordinated work flow. When teachers leave their jobs, it is often a sign that something is going wrong. In addition to the cost considerations in times of high attrition the Institutes have to face others problems too. Most academic activity of a department goes awry. All these issues together have a huge impact on the quality of education being delivered and ultimately spoiling the image of the institute. Therefore, in order to build reputation and offer quality education for the students, it is the duty of the management to look into the issues of teachers and solve the problems amicably at the earliest, thereby retaining the best faculty. So, in this study an attempt has been made to identify the factors that enhance job satisfaction of women staff members at Arts and Science Colleges in Coimbatore district.

\section{Review of Literature}

Pan Xiaofu and Qin Qiwen (2008) in their study ascertained that nature of the job, leadership, salaries and opportunities for advanced studies, promotion and physical conditions lead to Job Satisfaction.

Alam (2009) in his study finds that significant relationship exists between job stress and job satisfaction.

Bhandari, R.A. and Patil, N.H. (2009) in their study identifies that job satisfaction of women teachers depends on working environment, job nature and salary 
Singh (2009) in his study identifies that teachers working in aided colleges have high level of satisfaction than those working in selffinancing colleges.

Thukral and Kaur (2009) in their study identify that highly committed teachers have high level of Job Satisfaction.

Kayalvzhi and Shokkanathan K (2011) in their study identifies that lecturers are greatly dissatisfied with their jobs. The factors which are inherent for the job dissatisfaction are poor recognition for their work, low career growth, poor compensation and benefits offered by the institution.

Marrey (2011) in his study finds that job satisfaction significantly varies between male and female teachers, experienced and nonexperience teachers and teachers working in Government schools and private schools.

Singh and Pal (2011) in their study observes that job satisfaction varies between urban and rural teachers.

Tabassum Azmi . F and Mohan Sharma G (2012) in their study ascertains that there is a positive relationship with pay, supervision, work-schedule flexibility and teachers' job satisfaction.

Sotodeh Asl, N, Ghorbani, R., Haji Aghajani, S and RashidyPour, A. (2012) in their study identifies that the women faculties have highest level of job satisfaction with regard to nature of work assigned. They also point out that lack of support and non availability of proper feedback system affects their job satisfaction.

Nirav Dave and Dr. Dharmesh Raval (2014) in their study finds that faculty job satisfaction is associated with Satisfaction from classroom teaching, Training and Faculty Development Programs, Performance Appraisal, Cooperation and behavior of peers(colleagues), Physical Working Condition, Student interaction, Students IQ, Student Curiosity, Eagerness to learn, Recognition for Extra Work/Qualitative Work, Objectives and Clearly defined promotion policies, Salary, Participation in Decision Making, Management style/Management philosophy/vision/mission/strategy at top management, Challenging \& Interesting Work, Job Security, Organization Culture, Support for Research Environment in Organization and the reputation of organization in the market.

Malarvizhi, K and M. Jaya (2015) in their study state that demographic variables namely age, educational qualification and experience play a significant role in job satisfaction.

Thirumaran, J and A. Ramasethu (2015) in their study state that overall job satisfaction among the college faculty members depends on hygiene factors.

Murugeswari, K. Kamalakannan and. V. Sangeetha (2015) in their study find that personal factors like age, marital status, nature of family, educational qualification, designation, total teaching experience and nature of employment seldom influence the level of job satisfaction.

Unnamalai, $T$ (2015) in his study identifies that the salary, working environment, promotional opportunity and interpersonal relationship are the main factors influencing job satisfaction.

Senthilkumar, V and Dr. R. Kannappa (2016) in their study state that salary, working environment, promotional opportunity and interpersonal relationship are the main factors influencing job satisfaction

Parimalakanthi, K and V. Divya (2016) in their study state that women faculty are happy with their working condition, working hours and bond with students and colleagues.

\section{Statement of the Problem}

The most significant and effectual feature in any educational organization is the teacher. It is the teacher, who molds the character of students, instill in them values, encourages and enlarges their capabilities to their full potential and make them ready to serve society and the nation.

Management of educational system is related to the administration of institutions, where human beings as well as materials are assembled collectively for attaining educational goals. Similar to other managements, educational managements also require an extremely devoted, idyllic and happier teachers. Teachers' approach, inspiration and job satisfaction are obviously very vital factors to any educational organizations. Teachers' satisfaction, along with high quality of output is a milestone of well-managed educational organization. Apart from the core responsibility of teaching, evaluating, planning and guiding, a teacher is expected to do numerous other activities, like conducting co-curricular activities, ongoing professional development etc. The study of job satisfaction of college teacher will give an indication to the management about the general levels of satisfaction and its related variables in an educational organization.

Further, management of higher education needs information on teachers and employees' job satisfaction in order to make sound decisions, both in preventing and solving employees' problems. Thus, the success of any educational system depends largely on the job satisfaction of the teachers.

The changing trend of higher education requires experienced teachers to manage themselves with the new change in the horizon of knowledge, methods and technique of teaching and proper use of technology in teaching and learning.

The success of a teacher certainly depends on his satisfaction in the job.

Simultaneously, it is also fact that the development of students on the one hand and socio-economic transformations on the other make society and human life complex making job satisfaction all the more difficult to achieve.

So, in this study an attempt has been made to identify the factors that influence Job satisfaction of teachers.

\section{Objectives of the Study}

1. To find the Socio-economic profile of women faculty.

2. To ascertain factors influencing Job Satisfaction among Women faculty.

\section{Research Methodology}

The study is an analytical research based on the survey method. The method adopted for data collection and sample design are described in the following paragraphs.

\section{Data}

Data required for the study are primary in nature. Thus, primary data are collected by making use of questionnaires. Questions pertaining to personal profile of women faculty and questions pertaining to Job satisfaction are included in the questionnaire.

\section{Sample Design}

By adopting convenient sampling method questionnaires are distributed to 750 women faculty working at various Arts and Science Colleges in Coimbatore district. Of which, 200 faculty have not returned their questionnaires and 35 faculty have not filled in the questionnaires in full. Hence, the 515 forms the sample size of the study.

\section{Framework of Analysis}

The collected data have been analyzed by making use of (1) Simple Percentage and (2) Factor Analysis.

\section{Analysis and Interpretation}

\section{Socio Economic Profile}


The following table portrays the socio economic profile of select women staff members working in Arts and Science Colleges in Coimbatore district.

Table 1: Socio Economic Profile of Women Staff Members

\begin{tabular}{|c|c|c|c|}
\hline Variables & Number $(\mathrm{n}=515)$ & Variables & Number $(n=515)$ \\
\hline \multicolumn{2}{|r|}{ Age } & \multicolumn{2}{|c|}{ Area or Residence } \\
\hline Up to 25 & $118(22.90)_{-}$ & Urban & $199(38.60)$ \\
\hline 26 to 40 & $293(56.90)$ & Semi urban & $199(38.60)$ \\
\hline Above 40 & $104(20.20)$ & Rural & $117(22.70)$ \\
\hline \multicolumn{2}{|c|}{ Marital Status } & \multicolumn{2}{|c|}{ Type of Family } \\
\hline Married & $353(68.50)$ & Joint & $241(46.80)$ \\
\hline Unmarried & $162(31.50)$ & Nuclear & $274(53.20)$ \\
\hline \multicolumn{2}{|c|}{ Educational Qualification } & \multicolumn{2}{|c|}{ Earning Members } \\
\hline PG & $56(10.90)$ & One & $28(5.40)$ \\
\hline M.Phil. & $332(64.50)$ & Two & $365(70.90)$ \\
\hline Ph.D. & $127(24.70)$ & Above Two & $122(23.70)$ \\
\hline \multicolumn{2}{|c|}{ Monthly Income } & \multicolumn{2}{|c|}{ Family Income } \\
\hline Up to 15000 & $23(4.50)$ & Up to 30000 & $44(8.50)$ \\
\hline $15001-30000$ & $441(85.60)$ & $30001-60000$ & $294(57.10)$ \\
\hline Above 30000 & $51(9.90)$ & Above 60000 & $177(34.40)$ \\
\hline
\end{tabular}

(Source: Primary Data)

- Out of 515 women staff members; 118 (22.90) women staff members are within the age of 25 years; 293 (56.90) the age of women staff members ranges between 26 and 40 years and that of the rest 104 (20.20) are above the age of 40 years.

- One hundred and ninety nine (38.60) women staff members reside in Urban area; 199 (38.60) in Semi-urban area and the remaining 117 (22.70) in rural area.

- Three hundred and fifty three (68.50) women staff members are married and the rest 162 (31.50) unmarried.

- Two hundred and forty one (46.80) women staff members belong to joint family and the remaining 274 (53.20) to nuclear family.

- Fifty six (10.90) women staff members have Postgraduate educational qualification; 332 (64.50) have M.Phil., educational qualification and the rest 127 (24.70) have Doctorate educational qualification
- Twenty eight (5.40) women staff members have one earning member in their family, 365 (70.90) two and the rest 122 (23.70) more than two. Thus, majority of the women staff members have two earning members in their family.

- The monthly income of twenty three (4.50) women staff members ranges up to Rs. 15000; that of 441 (85.60) ranges from Rs. 15001 to Rs. 30000 and that of the rest 51 (9.90) above Rs. 30000.

- The family income of forty four (8.50) women staff members ranges up to Rs.30000, that of 294 (57.10) between Rs.30001 and Rs. 60000 and that of the remaining 177 (34.40) above Rs. 60000.

\section{Factors Influencing Job Satisfaction}

To identify the prominent factors that enhance women staff member's job satisfaction, Factor Analysis is employed. The following table portrays the significant factors that increase women staff members job satisfaction. Kaiser-Meyer-Olkin (KMO) and Bartlett's Test of Sphericity has been used as preanalysis testing for suitability of the entire sample for factor analysis. The result of KMO and Bartlett's Test is found greater than 0.70 . Hence, the collected data is fit for employing factor analysis. Further, the large values of Bartlett's sphercity test (1474.713, df: 465, Sig=0.000) and KMO statistics (0.755) indicated the appropriateness of factor analysis i.e., the sample was adequate.

Table 2: KMO and Bartlett's Test

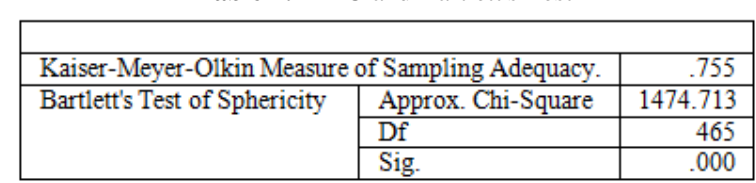

Table 3: Job Satisfaction of Women Staff Members

\begin{tabular}{|c|c|c|c|c|c|c|c|c|c|c|c|c|}
\hline Factors & 1 & 2 & 3 & 4 & 5 & 6 & 7 & 8 & 9 & 10 & 11 & 12 \\
\hline Salary & 0.004 & 0.098 & 0.677 & -0.036 & 0.057 & -0.126 & -0.007 & 0.139 & -0.108 & 0.034 & 0.006 & -0.037 \\
\hline Promptness in Salary Payment & 0.023 & 0.504 & 0.424 & 0.130 & -0.114 & 0.110 & -0.099 & -0.067 & 0.084 & 0.119 & -0.306 & -0.054 \\
\hline Revision of Salary & 0.636 & 0.016 & 0.305 & 0.048 & -0.085 & -0.028 & 0.300 & -0.193 & -0.065 & -0.051 & 0.020 & 0.014 \\
\hline Frequency of Salary Revision & 0.066 & -0.059 & 0.544 & 0.047 & 0.342 & -0.004 & 0.113 & -0.049 & 0.124 & 0.298 & 0.000 & -0.031 \\
\hline Increment of Additional Qualification & 0.133 & 0.002 & 0.556 & 0.022 & 0.026 & 0.303 & -0.174 & -0.097 & 0.074 & -0.076 & 0.074 & 0.326 \\
\hline Promotion Policy & 0.217 & -0.090 & 0.246 & -0.165 & 0.290 & -0.043 & 0.079 & 0.015 & 0.373 & -0.191 & -0.391 & 0.179 \\
\hline Superior's Support & -0.028 & -0.004 & 0.009 & 0.040 & 0.036 & 0.713 & 0.135 & 0.093 & 0.136 & 0.053 & 0.019 & -0.123 \\
\hline Colleague's Support & -0.008 & 0.067 & -0.012 & 0.158 & -0.199 & 0.084 & 0.123 & -0.129 & 0.752 & 0.018 & -0.063 & -0.036 \\
\hline Work Autonomy & 0.133 & 0.036 & 0.038 & 0.048 & -0.026 & 0.036 & -0.003 & -0.026 & 0.036 & -0.070 & 0.828 & 0.087 \\
\hline Subject Allotment & 0.032 & -0.014 & 0.094 & 0.423 & 0.084 & 0.397 & -0.054 & -0.080 & -0.056 & -0.157 & 0.272 & -0.101 \\
\hline Allotment of Preferred Class & 0.012 & -0.089 & 0.011 & 0.633 & -0.103 & 0.230 & 0.023 & -0.060 & 0.092 & 0.130 & -0.050 & -0.107 \\
\hline Recognition form Superiors & 0.722 & 0.072 & -0.077 & 0.039 & 0.116 & 0.080 & -0.067 & 0.069 & 0.061 & 0.123 & 0.114 & -0.024 \\
\hline Team Spirit & 0.070 & 0.046 & -0.020 & 0.661 & 0.031 & -0.133 & 0.059 & 0.238 & 0.003 & -0.048 & 0.078 & 0.130 \\
\hline Teaching Aid & 0.034 & 0.059 & 0.046 & -0.110 & 0.115 & 0.344 & 0.542 & 0.005 & -0.042 & -0.056 & -0.001 & 0.007 \\
\hline Workload & 0.008 & -0.036 & 0.013 & 0.233 & 0.386 & -0.286 & 0.018 & 0.227 & 0.143 & 0.316 & 0.115 & -0.033 \\
\hline Leisure Hours & 0.018 & 0.099 & 0.127 & -0.091 & 0.745 & 0.155 & 0.047 & -0.091 & -0.070 & 0.004 & -0.029 & -0.033 \\
\hline Working Time & 0.098 & 0.098 & -0.067 & -0.039 & 0.279 & 0.016 & -0.249 & 0.191 & 0.582 & 0.044 & 0.152 & 0.121 \\
\hline Professional Growth & -0.049 & 0.085 & -0.006 & 0.052 & -0.070 & 0.126 & 0.123 & 0.744 & -0.021 & 0.005 & -0.036 & 0.069 \\
\hline Grievance Redressal Mechanism & 0.456 & 0.058 & 0.170 & 0.115 & 0.187 & -0.090 & -0.018 & 0.497 & 0.041 & 0.160 & 0.001 & -0.105 \\
\hline Number of Holidays & 0.220 & 0.207 & 0.082 & 0.302 & 0.445 & -0.026 & 0.052 & 0.082 & -0.087 & -0.263 & -0.248 & 0.193 \\
\hline Library Facility & -0.330 & 0.470 & 0.086 & 0.060 & 0.126 & 0.129 & 0.320 & 0.146 & -0.031 & -0.253 & 0.171 & 0.081 \\
\hline Water Facility & 0.030 & 0.584 & 0.018 & -0.181 & 0.196 & -0.019 & 0.123 & 0.076 & 0.100 & 0.233 & 0.122 & -0.073 \\
\hline Canteen Facility & 0.048 & 0.050 & -0.089 & 0.132 & -0.008 & -0.096 & $\mathbf{0 . 7 8 2}$ & 0.116 & 0.028 & 0.093 & -0.024 & 0.033 \\
\hline Toilet Facility & 0.379 & 0.567 & 0.071 & -0.050 & -0.071 & 0.052 & -0.006 & 0.257 & -0.051 & 0.004 & -0.063 & 0.021 \\
\hline Students Co-operation & 0.078 & 0.114 & 0.123 & 0.045 & -0.081 & 0.045 & -0.041 & 0.125 & -0.057 & 0.701 & -0.008 & 0.094 \\
\hline Obedience of Students & 0.131 & 0.108 & 0.007 & -0.126 & 0.221 & 0.049 & 0.207 & -0.281 & 0.023 & 0.491 & -0.248 & 0.054 \\
\hline Students Attention & 0.261 & 0.308 & -0.089 & 0.231 & 0.078 & -0.051 & 0.039 & -0.009 & -0.397 & 0.172 & 0.005 & 0.214 \\
\hline Infrastructure at Classroom & 0.006 & 0.475 & -0.107 & 0.282 & 0.164 & -0.203 & 0.011 & -0.255 & 0.006 & 0.002 & 0.055 & 0.127 \\
\hline Ventilation at Classroom & -0.029 & 0.037 & 0.097 & -0.005 & 0.029 & 0.145 & 0.058 & 0.042 & -0.058 & 0.004 & 0.038 & 0.047 \\
\hline Layout of Classroom & 0.117 & 0.054 & -0.199 & 0.123 & 0.092 & 0.450 & -0.107 & 0.142 & -0.046 & 0.157 & -0.032 & 0.391 \\
\hline Strength of Class & -0.078 & -0.016 & 0.073 & -0.025 & -0.023 & -0.116 & 0.072 & 0.013 & 0.016 & 0.071 & 0.058 & 0.836 \\
\hline Eigen Values & 3.089 & 1.801 & 1.583 & 1.510 & 1.355 & 1.310 & 1.205 & 1.174 & 1.138 & 1.104 & 1.059 & 1.031 \\
\hline$\%$ of Variance & 9.964 & 5.810 & 5.106 & 4.870 & 4.372 & 4.227 & 3.888 & 3.786 & 3.669 & 3.560 & 3.416 & 3.324 \\
\hline Cumulative \% of Variance & 9.964 & 15.774 & 20.880 & 25.750 & 30.122 & 34.349 & 38.237 & 42.023 & 45.692 & 49.253 & 52.669 & 55.993 \\
\hline
\end{tabular}


be seen that "Recognition form Superiors" and "Revision of Salary" have a component loading of 0.5 and above. Hence, these two variables form the first factor.

In the second factor, "Water Facility", "Toilet Facility" and "Promptness in Salary Payment" are found to be significant.

In the third factor, "Salary", "Increment of Additional Qualification" and "Frequency of Salary Revision" are found to be significant.

In the fourth factor, "Team Spirit", and "Allotment of Preferred Class" are found to be significant.

In the fifth factor, "Leisure Hours" is found to be significant.

In the sixth factor, "Superior's Support" is found to be significant.

In the seventh factor, "Canteen facility", and "Teaching Aid" are found to be significant.

In the eighth factor, "Professional Growth" is found to be significant.

In the ninth factor, "Colleague's Support", and "Working Time" are found to be significant.

In the tenth factor, "Students Co-operation" is found to be significant.

In the eleventh factor, "Work Autonomy" is found to be significant.

In the twelfth factor, "Strength of Class" is found to be significant. Factor one contributes to a tune of 9.964 per cent towards women staff members' job satisfaction. The other factors contribute 5.810 $5.106,4.870,4.372,4.227,3.888,3.786,3.669,3.560,3.416$ and 3.324 respectively towards women staff members' job satisfaction. The total cumulative percentage of contribution by these twelve factors towards women staff members' job satisfaction accounts for 55.993 per cent.

\section{Findings}

- Majority of the women staff members' age ranges from 26 to 40 years.

- Most of the women staff members reside in urban and semiurban area.

- Majority of the women staff members are married.

- Majority of the women staff members belong to nuclear family.

- Majority of the women staff members have M.Phil., educational qualification.

- Majority of the women staff members' monthly salary ranges $\begin{array}{llll}\text { from } & \text { Rs. } & 15001\end{array}$ Rs. 30000.

- Majority of the women staff members' family income ranges from Rs.30001

Rs. 60000

- The result of Factor analysis discloses that a majority of the women staff members are satisfied with regard to recognition received by them from their superiors for the work performed followed by revision of salary done by management, provision of adequate basic facilities like water and toilet by the management, salary offered and increment offered by the management for acquiring additional educational qualification etc.

\section{Suggestions}

- Senior faculty in any colleges may appreciate newly joined faculty for performing the assigned tasks.

- College management should devise suitable policies for effective mobilization and management of finance, which assists management for timely revision of salary to their employees without hindrance.

- Employee satisfaction also depends on the perception of employees on Quality of Work Life. Thus, in order to raise their satisfaction level, management should provide sufficient infrastructure facilities like provision of sufficient water, toilet facilities, canteen facility, teaching aids, etc.

- For the new recruits, senior faculty may allot preferred subjects, thereby helping them handle classes efficiently, which ultimately enhances their job satisfaction.

- Management should offer sufficient freedom and facility for the career growth of faculty.

- Management should fix working time convenient for both students and faculty, so that personal life and professional commitment may not be affected.

- Moreover, students should properly oblige their teachers, which surely increase the faculty job satisfaction.

- Sufficient autonomy should be offered by the management to the faculty on decision making on routine affairs.

\section{Conclusion}

The result of the study discloses that a majority of the women staff members are satisfied with regard to recognition which they have received from their superiors followed by salary offered by the management, increment offered by the management for additional qualification acquired and periodicity of salary revision by the management. The development of any educational institution rests on dedicated and committed faculty and dedication and commitment are born out of job satisfaction. Therefore, the management may look into the grievances faced by teaching community in their institutions and try to redress them, which may contribute considerably to the growth of the institution.

\section{Scope of Further Research}

The present study has concentrated on identifying factors influencing Job satisfaction of Arts and Science College faculty in Coimbatore district. A study of similarly nature may be carried out among faculty working at Higher Secondary Schools. The work time of Doctors and Police are not fixed, hence a study may be carried out on ascertaining the Job Satisfaction of Doctors and Police and how well they are managing their work and personal commitments.

\section{References}

11] Pan X \& Qin Q, "An Analysis of the Relation between Secondary School Organizational Climate and Teacher Job Satisfaction", Chinese Education and Society, Vol.40, No.5, (2008), pp.65-77.

[2] Kayalvzhi S \& Chokkanathan, K, "A study on factors influencing the Job Satisfaction of Lecturers employed in Self Financing Arts Colleges South India", International Journal of Research in Commerce and Management, Vol.2, No.5, (2011), pp.58-65.

[3] Tabassum AF \& Mohan SG, "Job Related Dimensions and Faculty Members Satisfaction at Indian Business Schools: An Empirical Study", International Journal of Management and Business Research, Vol.2, No.1, (2012), pp.23-40.

[4] Sotodeh Asl N, Ghorbani R., Haji Aghajani S \& Rashidy-Pour A., "Job Satisfaction and its Contributing factors among Faculty Members of Semnan University of Medical Sciences", Koomesh, Vol.14, No.2, (2012), pp.232-239.

[5] Malarvizhi K \& Jaya M, "Job Satisfaction of Women Academicians (With Special reference to Self-Financing Colleges in Chennai)", International Journal of Business and Administration Research Review, Vol.3, No.10, (2015), pp.164-169.

[6] Thirumaran J \& Ramasethu A, "A Study on Job Satisfaction among the Arts and Science College Faculty (with special reference to Coimbatore District, Tamil Nadu)", International Journal of Core Engineering and Management, Vol.2, No.8, (2015), pp.1-8.

[7] Murugeswari M, Kamalakannan K \& Sangeetha V, "A Study on Job Satisfaction Level of Women Teachers Working in Arts and Science Colleges", International Journal in Commerce, IT \& Social Sciences, Vol.2, No.3, (2015), pp.11-16.

[8] Unnamalai, T, "A study on factors influencing job satisfaction of faculty members with special reference to Arts and Science 
colleges in Tiruchirapalli”, International Journal of Management, Vol.6, No.1, (2015), pp.161-170.

[9] Senthilkumar V \& Kannappa R, "A Study on Employees Job Satisfaction in Collegiate Education with Special Reference to Arts and Science Colleges at Trichy in Tamilnadu", IOSR Journal of Business and Management, Vol.18, No.3, (2016), pp.5-11.

[10] Parimalakanthi K \& Divya V, “A study on Job Satisfaction among Women faculties of Self-financing Arts and Science Colleges in Palakkad", International Conference on "Research avenues in Social Science, Vol.1, No.3, (2016), pp. 235-242.

[11] Ausekar P, "A study of Job-satisfaction among teachers working in Government \& private secondary schools", Progress of Education, Vol.71, (1996), pp.50-53.

[12] Alam, SS, "A Study of Job Stress on Job Satisfaction among University Staff in Malaysia", European Journal of Social Sciences, Vol.8, No.1, (2009), pp.105-128.

[13] Kumar R, Bhandari A \& Patil NH, "Job Satisfaction of Women Teachers", Edutracks, Vol.8, No.11, (2009).

[14] Thukral P \& Kaur R, "A Study of Relationship between Professional Commitment and Job Satisfaction of Teachers", Education New Horizons- A Quarterly Journal of Education, (2009).

[15] Marrey, JP, “A Study of the Difference in Intensity of Relationship between Teachers Freezing and Job Satisfaction of Secondary School Teachers", Journal of Educational and Psychological Research, Vol.1, No.2, (2011), pp.89-95.

[16] Singh JD \& Pal S, "A Study of Job Satisfaction and Teaching Effectiveness of Primary and Upper Primary School Teachers of Bikaner Regions", Journal of Educational and Psychological Research, Vol.1, No.2, (2011).

[17] Nirav D \& Dharmesh R, "A research on the factors influencing job satisfaction of MBA faculty members in Gujarat state", International Journal of Advance Research in Computer Science and Management Studies, Vol.2, No.2, (2014), pp.218-223. 